\title{
СРПСКИ ГОВОРИ И(ЛИ) ГОВОРИ СРПСКОГА ЈЕЗИКА
}

\footnotetext{
У раду се анализира укрштање социолингвистичких и лингвистичких фактора у дефинисању ,језика̂" на средишњем исечку јужнословенског континуума - простору српскога језика, с богатом документарном посведоченошћу његова имена. Логичким и лингвистичким законитостима спајају се дијахронијска и синхронијска перспектива, у циљу утврђивања опсега овога језика у хронолошки и географски задатим оквирима.

Кључне речи: српски језик, српски говори, говори српскога језика, историја језика, дијалектологија.
}

У средишту нашег занимања јесте проблем одређења српскога народног језика као [апстрактног] скупа народних говора и транслације његова имена на поједине уже скупине. За пружање ваљаног одговора нужно је утврђивање горње хронолошке границе (terminus ad quem): то је 1991/1992. година, када су разорени оквири у којима је на широком, културно и духовно издиференцираном простору постојао овај наддијалекатски систем и, што је још важније, дошло је до померања, па и трајног уклањања различитих скупина становништва, говорника овога језика. ${ }^{1}$ Питање међусобно повезаних говора који чине српски језик нужно је дијахронијског карактеpa, не само због хронолошке границе. За овакав систем, с дистрибуцијом која се мењала на терену (особито крај XIV - почетак XIX в.), потребно је испратити развојне процесе у дугачком распону. Под претпоставком да се апстрахује познопрасловенски период на датоме тлу, то је време од прелаза $\mathrm{X} / \mathrm{XI}$ - до свршетка XX в.

\footnotetext{
*viktor.savic@isj.sanu.ac.rs

1 Засебни параметри важе за околне државе на чији простор се такође „прелива” српски језик.
} 
У XIX в. су започети шири процеси „обједињавања” српске и тзв. „илирске" језичке културе ${ }^{2}$ (више једностраног, него обостраног карактера). ${ }^{3}$ Вук Караџић је, иако је и сам имао извесног удела у томе, положио основе правилном разумевању односа између српскога народног језика и на њега наслоњених или с њиме у додиру блиских словенских језичких система (Вук 1849). Накнадно пројектовање књижевног језика и његова имена („српскохрватски" или сл.) на народне говоре, па и читаву историју вернакулара и старијих књижевнојезичких формација, те потом издвајање из целине засебних „стандардних језика", временом је искривило и растројило основне инструменте за разумевање оригиналног језичког система. ${ }^{4} \mathrm{Jep}$, колико је у међувремену „произведено” нових стандардних језика растакањем језичке заједнице, толико се, ретроактивно, сада дефинише нових народних база, па и засебних историјских развоја. Лингвистици је ово супротстављено. Узму ли се у обзир само органски идиоми, разлике међу јужнословенским говорним скупинама толико су мале, ${ }^{5}$ да се у збиљи може говорити о једном ${ }^{6}$ или два, највише три јасније диференцирана језичка система. Они се, сходно географским секторима у којима су образовани, могу одредити као „југоисточни”, „средишњи”, „северозападни”. Међу њима једини у сваком смислу афирмисан, с трајним именовањем по народу чије је културно-комуникацијско средство од средњег века до изградње модерних књижевних језика, јесте средишњи језички дијасистем - српски. Неупитно је да овде, после свих миграција, ${ }^{7}$ као затечено стање, имамо један јужнословенски дијалекатски (микро)континуум, исечак у широј целини. На самом терену то не значи постепене прелазе - осим у оквиру истих говорних ланаца или на потезима који су дуго остајали пасивни. Ту се ради о замршеним дијалекатским односима насталим сударањем и преклапањем говорних трајекторија на читавом [апстрактно] заокруженом простору, које су условљавали културни, политички, економски и др. разлози. И да оставимо по страни идентитетска питања - унутар средишњег дијалекатског комплекса нема простора за оделиту историју неког од ,језика̂”, јер је то део једног дијалекатског и историјскојезичког (микро)континуума. Сто-

${ }^{2}$ Илирско је овде име секундарнога карактера; „илирци” су учесници идеолошког покрета (1835-1843), док је „Илирима” називан народ који говори штокавским наречјем, поглавито у католичкој пропаганди и у државним системима с њоме повезаним, али и изван тога (углавном позни XVI-XVIII в.). О називима етничких група у првој половини XIX в. говори Вук 1849: 2-9.

${ }^{3} \mathrm{O}$ томе да су језичком уједињењу више тежили Хрвати од Срба данас отворено говоре и неки од лингвиста из хрватске средине (Кордић 2018: 72-73; 209; уп. Нејлор 1996: 19). Показано је да је у тадашњој Хрватској и Славонији прихваћен српски језик који је кодификовао Вук Караџић (нпр. Нејлор 1996: 5, 18-20, 26-28 итд.; уп. Стојановић љ. 1896: 28-29). За старији период, пре Вука, и закључно с њиме исто је потврдио В. Јагић: „Уже в 1636 году в Загребе признают этот язык, который назвали сначала Иллирским, а потом и Хорватским. Но в сущности это ничто иное, как сербский народный язык” (Пипер 1988: 81).

${ }^{4} \mathrm{O}$ односу књижевног и стандардног језика доста је писано (нпр. Брозовић 1970: 14-16).

${ }^{5}$ П. Ивић је утврдио да се изоглосе „по правилу не поклапају с границама између ових језика“, осим по изузетку, те да „границе [...] имају само врло релативну вредност за науку” (Ивић П. 1991/I: 167, 169).

${ }^{6}$ О проблемима издвајања појединачних језика у говорном континууму в. Ивић П. 2018: 195; уп. Бугарски 2001: 9-10, Бугарски 2010: 25-27.

${ }^{7}$ Сматра се да су миграције један од најважнијих елемената српске историјске дијалектологије, па и читаве етничке историје (уп. Ивић П. 1991/III: 81; Ивић П. 2001: 64-73). 
га, постоји само једна језичка историја на посматраном простору - српскога народног језика или било којег другог од новонасталих ,језика": не може их постојати више истовремено.

Социолингвистичко реинтерпретирање статуса мноштва народних говора као међусобно повезане целине у кључу једнога, српскохрватског књижевног језика под чијим су се фиктивним обухватом нашли, лингвистички је промашено. Овај принцип био је примарно важан хрватским лингвистима јер су тобоже социолингвистичким путем, а заправо држећи се „државног права" са савремених позиција протезали једно оживљено име којим је замењивано старо, оживљено, уз истискивање затечених регионалних имена. Тако су различите етничке скупине спојене у нацију која ће, потом, градити романтичарску слику о властитој прошлости. Државно и идеолошко спајање простора с кајкавским, чакавским и штокавским говорима у једну језичку заједницу у новој комуникативној сфери уз помоћ књижевнога језика није ништа мање необично од прокламованог хибрида с чудним именом „српско-хрватско-словеначкога” језика у југословенској краљевини (19181941). На нивоу народних говора ништа се битније није променило, оставимо ли по страни билингвалну интерференцију. И даље су наставили владати специфични и несиметрични односи између чакавштине, кајкавштине и штокавштине (уп. Ивић П. 1991/II: 185-187, 187-188; Ивић П. 2001: 46-50; Ивић П. 1991/II: 160-175; Ивић П. 1991/I: 222-223; Ивић П. 1991/III: 34-47), што није чудно будући да су њихови фонолошки системи оформљени већ око XI в. (в. Ивић П. 1991/II: 160). ${ }^{8}$ Дакле, кајкавско-чакавско-штокавска језичка заједница није постојала пре узимања једног говорног модела за наддијалекатски језички образац у функцији књижевног, доцније стандардног језика (уп. Кордић 2018: 71-72). Таква заједница није постојала ни након тога јер је за потребе књижевног језика изграђена нова заједница другачијег типа, пре свега преко школског система и уједначавања јавне речи, у принципу незаинтересована за засебне дијалекатске подлоге, чијом би се промоцијом непотребно слабила интегративно-комуникацијска улога одабраног средства. Па опет, наведени принцип су прихватили југословенски лингвисти са српског културног подручја, потоњи српски, у настојању да схвате оквире у којима постоји или је постојала српскохрватска језичка заједница, односно у настојању да објасне ,докле сеже” српски језик, а „одакле почињу” други језици после деструкције заједнице. То се понекад своди на сабијање или ширење опсега народног језика на државне или политичке границе. Може ли се доводити у исту раван стандардни српски језик, на пример, с говором неког села или скупине села, чак и да се ради о Вукову Тршићу? У науци о језику то нема смисла: јасан је сигнал одсуства оријентације и огрешења о научну методологију. Књижевни, односно стандардни и народни језик феномени су различитога реда; они настају и функционишу суштински другачије (Брозовић 1970: 10-13, 27). Иако у српском случају књижевни језик јесте на-

\footnotetext{
${ }^{8}$ Кајкавски и словеначки говори одвојени су снопом изоглоса од чакавских и штокавских говора, што П. Ивић објашњава сродством међу прецима - носиоцима прва два говорна типа пре сеобе у садашње пределе (Ивић П. 1991/I: 247).
} 
стао на подлози народног језика, било је то уз неопходан степен апстракције, нормализације и сруктурног подешавања, толико различитог од стихијског постојања народних говора (за кодификацију в. Радовановић 2003: 186-197). Мешање стандардологије и њених принципа с дијалектологијом или историјом народнога језика нема упоришта у науци о језику.

Стандардни језик, у односу на књижевни уколико му претходи, тесно је повезан с нововековном идејом нације, на тлу Југославије нешто другачије него у остатку Европе. Српска нација није настала у XIX в., она је формирана у средњем веку - потпуно уобличење је стекла у XIII в. с изградњом култа преподобног Симеона и светитеља Саве, „отачаствуљубаца” и небеских заштитника свога рода. Томе су сведочанство бројне потврде изразите националне свести и националног деловања у српској историји. У време обнове Пећке патријаршије обновљено је и учвршћено унутрашње јединство народа и постављени су темељи данашњег идентитета (1557). Велика сеоба само је изменила демографску слику и географску дистрибуцију, не и суштину. Модерну српску нацију изнедриле су Српска револуција и обнова државности (1804-1835). О првим суседима на западу, пак, Хрватима, мало и недовољно се знало, чак и у Хабзбуршкој монархији где су они, тј. њихови етнички остаци и позни политички изданци претрајали до друге пол. XIX в. Бранећи у Кьижевнику Вукове заслуге, Јагић цитира Добровског, Копитара и др., показујући да ни они сами нису били начисто с тиме шта су „Хорвати” (1864: 483-484).

Више је крупних последица неадекватног посматрања језичких појава на терену, укључивањем политичко-идеолошких (тобоже социолингвистичких) параметара у објашњењу дијахронијских предстандардолошких феномена. О томе смо у другим приликама већ говорили, па ћемо истаћи само неке примере. Западни, северозападни и југозападни говори у односу на данашњу Србију, уз њих и споменици с истога подручја, отржу се из српске културе: на пример, Повеља бана Кулина постаје спомеником „босанскога” језика из XII в. када нити је било језика с тим именом, нити дубоких разлика међу штокавцима. ${ }^{9}$ Текстови везани за католичку пропаганду од краја XVI в. на тзв. „илирском” језику, ${ }^{10}$ укључују се у „хрватску” културну историју. Књиге дубровачких католика увелико се издају као хрватски споменици, па чак и преписи српске канцеларије сада су „хрватски”. У нама суседној западној науци системски се негира постојање Срба у западним крајевима, и у историографији они се замењују „Власима” источног обреда. ${ }^{11}$ У дијалектолошке

${ }^{9}$ П. Ивић је показао да је штокавско подручје до сред. ХІІІ в. „континуиран дијалекатски пејзаж”, незнатно рашчлањен (Ивић П. 1991/II: 185).

${ }^{10}$ У Лорету је 1580. године основан Илирски колегиј, касније мењан и премештан, у којем су радили професори језуити (в. Јачов 1986: 18). За потребе католичког прозелитизма одабрано је штокавско наречје којем је наденуто „илирско” име, па језуита Б. Кашић 1604. издаје прву „Граматику илирског језика“. И В. Јагић је признао да се овде радило о српском језику: „Это грамматика народного сербского языка, среднего между штокавизмом и чакавизмом”, 1884/1885 (Пипер 1988: 81). Од посебног је значаја делатност Св. конгрегације за ширење вере, основане 1622. године.

${ }^{11}$ Што важи данас, важило је и у прошлости, када је о томе писао А. Ивић: „Хрвати имају на хиљаде књига и студија о прошлости Хрватске и Славоније и у свим тим историјским делима 
прегледе доследно су укључене оазе данас с хрватским становништвом по Србији и с католицима у Мађарској и Румунији. „Показано” је тиме да нема ниједнога штокавског дијалекта који није [и] хрватски (в. Лисац 2003: 9), па је закључено да је штокавски језички тип - хрватски (Савић 2020: 341).

Прастара граница између западних и источних јужнословенских говора и њена доцнија сталност нису без остатка утврђени. Споменици с помешаним западним и источним цртама углавном се смештају у митски простор истовремено тешко спојивих бугарско-македонско-српских црта, као да је постојао такав древни дијалекат. Па и у нашој дијалектологији северни говори Вардарске Македоније доскора су сврставани у „македонске”, док није постало јасно да на том простору живи српска заједница. Једина граница у окружењу уз коју и са супротне стране нема српских говора, што се противи познатим чињеницама о основним правцима кретања из српских области - јесте бугарска. У природним околностима посвуда на словенском терену државна граница се не пресликава идеално на границу међу народним говорима. ${ }^{12}$ Тако је изграђен привид о постојању западнобугарских говора, што је бугарским историчарима дало покриће да тамо где установе промене ж > oy, ^ $>$ е и свођење оба полугласника на један (штокавске црте), виде бугарске споменике (уп. Савић 2020: 348). ${ }^{13}$

Србистика уопште, а нарочито наша дијалектологија, стешњена ванлингвистичким факторима, дистинкцију свога предмета, тј. српскога језика као дијалекатског система, повлачи према другим језицима из окружења по линији апстрактног омеђења стандардних језика у реалном простору, тј. у складу с критеријумом националног изјашњавања говорника. После разарања српскохрватске [стандарднојезичке] заједнице код нас се просудило да „српским можемо сматрати оне дијалекте којима говоре Срби, односно популације које свој језик називају српским. То су, у крупним цртама, сви штокавски дијалекти осим икавских, стариначких славонских и источнобосанских". Ипак, не хотећи да српску дијалектологију лиши релевантних чињеница за ваљан опис и целовито разумевање властитог предмета, уз пуне обзире према данас формираним Хрватима, Муслиманима („Бошњацима”), Македонцима и др., чији се говори не могу сматрати „српскима” иако су у саставу српских дијалекатских јединица, П. Ивић препоручује да их српска дијалектологија има у виду (2009: 7-9). Дакле, у изнудици, исти они параметри који су узети у обзир пре више од столећа да би се објаснило постојање српскохрватске заједнице, а сада сужене, па и накнадно сужаване, српске; нелингвистички

говори се о прошлости Хрвата и Влаха. Та два народа станују у тим земљама, а Срби [...] не постоје и нису никад ни постојали...” (Ивић А. 1922: 18-19).

${ }^{12}$ Наравно, српској науци није непознато да „на источној страни српско-бугарске границе и на јужној страни српско-македонске границе постоје бројни локални говори српског порекла“ (Ивић П. 2018: 292).

${ }^{13}$ У време настајања појединих редакција стсл. језика, говори призренско-тимочког типа који би тобоже припадали бугарском језичком корпусу још нису ни постојали (Ивић П. 1991/II: 185; Ивић П. 1991/I: 183). 
су оба пута. ${ }^{14}$ Пред нашим очима у више етапа се одигравао идентитетски преображај дела већинског живља у Црној Гори, с издвајањем из српскога националног корпуса (1943/1945-1948), али језичка заједница није нарушена: књижевни језик је остајао у истој, источној варијанти српскохрватског језика, с враћеним српским именом после пропасти СФРЈ, да би, првих година XXI ст., државном интервенцијом било уведено „црногорско” име за исти језик - све у истој језичкој генерацији. ${ }^{15}$ „Мењање” језичког идентитета једне генерације најбољи је доказ да стварне промене није ни било, него да је она фиктивнога карактера - а то у науци о језику не узрокује никакве промене. Иако су резултати с пописа из 2003. и 2011. године ишли српском језику у прилог, и поред манипулативно-присилнога смањења, нису уважени у Црној Гори. С једне стране видимо „државно право” да се језик назове по имену државе, с друге „национално право”, реализовано преко статистичког повезивања свих индивидуалних изјашњења на попису за пожељан резултат. Објективност исхода исказује се процентним табелама и картографским приказом који, чињеницом да се у неком месту, на пример, више од 50\% житеља изјаснило за „црногорски” језик, а мање од тога за „српски” - одговарајућу административну јединицу обележава као простор на којем се говори „црногорским” језиком (или обрнуто, у зависности од изјашњавања), што је апсурдно јер и даље сви житељи говоре истим језиком. У науци је скренута пажња да „изјашњавање говорника̂” није лингвистички критеријум у одређењу језика (Кордић 2018: 116-119; Ковачевић/Шћепановић 2011: 11); исто важи и за „право народа” да даје име властитом језику, непознато у свету (Кордић 2018: 119-122, Ковачевић/Шћепановић 2011: 12-13). ${ }^{16}$

Неко ће све побројане могућности назвати социолингвистичким приступом, али заправо се ради о политици и идеологији које су зашле у лингвистичку материју, замаскиране социолингвистичком терминологијом (уп. Кордић 2018: 109, 122-125). Социолингвистика као дисциплина сазревала је у САД; антрополози су испитивали индијанска племена, а дијалектолози урбане дијалекте увезеног језика или социолекте црначког становништва, ${ }^{17}$

\footnotetext{
${ }^{14}$ Овај је приступ науку довео у ступицу: „истражују се“ народни говори „босанског“ језика, „црногорског“ језика итд., иако су сами говорници физички старији од „властитих“ нових ,језика“. На ванлингвистичком плану не може се зауставити процес језичког преименовања, али у лингвистици он се не може тицати предмета који се није мењао - реалних говора. Иначе, дијалекта као система изведеног апстракцијом, заправо, осим дијалектолога̂, обични говорници (на нашем) простору нису ни свесни, они су свесни језика. Пошто је дијалекат искључиво у домену лингвистике - зашто би се наука у његову именовању прилагођавала политици или идеологији.

${ }^{15}$ Подробно о „случају“ в. Стојановић J. 2011: 170-238; уп. Ковачевић/Шћепановић 2011: 8-23, 113-119. Тзв. „црногорски“ је језик, дакле, добио име под претпоставком да постоји и пре него што је био створен. У општој лингвистици је раширено уверење, засновано на досадашњем искуству човечанства, да ,jезици као системи комуникације не настају нити нестају политичким декретом“ (Бугарски 2001: 13). Но, први изузетак ове врсте на југословенском простору било је проглашење „македонског“ језика 2. августа 1944, након чега је извршена његова кодификација (в. Нејлор 1996: 25).

${ }^{16}$ Главни критеријуми за одређење језика у лингвистици јесу структурни (типолошки), генетски и комуникативни (Ковачевић/Шћепановић 2011: 8-10; Кордић 2018: 97).

${ }^{17}$ Термин соичиолингвистика, поред др. блиских шире се примењује тек од 60-их година $\mathrm{XX}$ в. за област језичких студија за коју су исказале интересовање социологија, психологија и антропологија (Ивић М. 1996: 260; уп. Радовановић 2003: 219-257). Око заснивања
} 
где се суд о идентитету или језику доносио самоидентификацијом, анкетом. У таквој средини улогу националног, али и међунационалног језика имао је језик увезен са стране, задатог порекла и основних одлика, што је одредило и однос домаће лингвистике према њему. Незаинтересованост за историјску страну језика отворила је простор проучавању друштвених разлика у језику. Принципи развијани у контексту језичке ситуације за чије разумевање није битан дубљи историјски развој не могу важити за језичке формације које имају документовану историју. Ипак, генетски аспект не може се потпуно искључити чак ни у проучавању урођеничких језика јер је и он, заједно с типолошком анализом, битан за класификацију говорних система. Могло би се поставити питање: зар немамо у старијим српским изворима спонтано изјашњавање о имену језика истога типа. То, ипак, неће бити случај: довољно је широк круг потврда из различитих дијалеката у корелацији с историјским вестима о присуству српскога народа, које својом варијабилношћу показују хијерархијски однос (више говора различитога дијалекатског профила, односно текстова прожетих дијалекатским изразом носи име српскога језика). Постоје и докази замене релацијскога карактеролошким појмом ('који се односи на што' у сфери припадања /којега, чији/ $\rightarrow$ 'који је с особинама чега' /који, какав/), што се подупире и преносом српскога имена на именовање писма (писмо је „српско” и када се не користи српско име у етничкој употреби). Ипак, аутентичност осигурава дубља старина, до почетка стимулисаних идентитетских процеса (закључно с XV в.), у чему постоји веза с непатвореним изјашњавањем урођеника̂ о посебности сопственог племена. Овде су примери из различитих епоха - натпис из књиге повластица Руска Христофоровића о српском писму, уговор о штампању књига намењених дубровачким католицима (Колендић 1964: 75-79, Решетар 1938: XVIII-XXI), један од наслова фрањевца Матије Дивковића, који је своје писмо и даље звао „српским” (уп. Колендић 1964: 70), а језик артифицијелно, „словинским”, што је домаћи синоним ученијега, „илирскога”.

Un libro di privilegj in caratteri Serviani Књига повластица, 1395-1423 (Колендић 1964: 71) || Petrus Georgij Susich ex una parte et Fransciscus Ratchi Mizalouich ex alia parte cum Dei nomine simul contraxerunt societatem et collegantiam inter eos ... impressore librorum ... pro officiis Sancte Marie, evangeliis, epistolis et soliloquiis Sancti Augustinj stampandis in littera et idiomate serviano 1511 (СМ 2016: 122) || ПАач Блажєнє Днвнце Ю̈арнє, кон плач нұпнсавшн

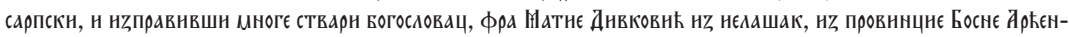
тннє Млеци, 1616 (уп. Колендић 1964: 74) - Навк карстнанскн Богоћлнвьнога Богословца фра Нlатна Днвковнћн а нъ нелашакь Реда Светога францешка ндь провннцце Босне Аргентннє. Овн навкь ретенн фра



Однос према предмету мења се када раздвојимо појам националне припадности, различит од етничке припадности, од феномена говора, тј. језика. Другим речима, није битно да ли су неки говори [и] данас „српски”, да ли се њима служе [искључиво или још и] припадници српскога народа јер не мора увек бити тако, него је битно којем језичком систему припадају. Руководећи

нове лингвистичке дисциплине „највише [су се] ангажовали представници антрополошке лингвистике [...] односно психолингвистике [...] (Ивић М. 1996: 260-261) 
се логиком и користећи се изражајним могућностима нашег језика, можемо установити јасну разлику између (а) „српских говора” (не подразумева се само по себи, али у датом контексту јесте - српскога језика), и (б) „говора српскога језика" (уп. Савић 2020: 343). Није исто исказано конгруентним атрибутом и падежним атрибутом с придевским значењем; у нашем случају то нису обичне позиционе варијанте. Присвојна придевска јединица у функцији конгруентног атрибута, с обзиром на творбено средство (суфикс -cк $(u)$ ), означава да се појам исказан мотивном речју непосредно тиче појма уз чије име стоји на два начина - припадањем или давањем особине (уп. Стевановић 1975: 546-548, т. 651). Присвојни генитив без предлога, пак, означава припадање у ширем смислу речи, као однос између дела и целине, или, још и више, типа и његове реализације. У првом случају, када се сагледава конкретно, непосредна је веза са Србима (српским народом), у другом случају веза је са српским језиком који, опет, са своје стране, преко синтагматског споја којим се изражава његово име - познаје оба блиска значења, као и претходни случај. „Српски говори” су овде, превасходно, говори Срба који говоре српским језиком; „говори српскога језика” су било који говори који припадају српском језику. Присвојним придевом изражава се и припадност и својство - из тога и идентификација по особини, присвојним генитивом изражава се припадност. Уз уважавање садашњега стања, „српски говори” су оних који не негирају да припадају српском народу уз претпоставку да говоре српским језиком, док говори који припадају језичком систему традиционално, али претежно и у науци од самих почетака словенске филологије називаном српским, ${ }^{18}$ јесу „говори српскога језика”. Посебне је тежине Миклошичев закључак да су штокавски, чакавски, кајкавски (уз словеначки) различити говорни системи, при чему је он српски језик изједначавао с језиком на штокавском подручју (Миклошич 1858: III). Његово је схватање поткрепио М. Решетар, закључујући да је „хрватски синоним за чакавски и обрнуто”, као и то да су „штокавски и српски као два идентична појма", уз упозорење да се овде ради само о првобитној разлици међу Хрватима и Србима (Решетар 1891: 387-388). Није од значаја да ли су то католички Арбанаси - Клименти у Срему који су усвојили српски језик у процесу који је трајао од XVIII до почетка XX в. (ЕJ 1955: 166-167), или било ко други. ${ }^{19}$ Ипак, у другој половини XIX в., по сту-

\footnotetext{
${ }^{18}$ Обимна је литература, нпр. сведено Ковачевић/Шћепановић 2011: 25. Истине ради, треба нагласити да је већ 1824. године Ј. Грим употребио придев „српско-хрватски“; Ј. Копитар је 1822. изједначавао „српски“ с „илирским“ језиком, да би у издању Клочева зборника „илирски дијалекат“ поистоветио са „српскохрватским или хрватскосрпским“. Али, неспорно је да се у том времену „хорватски“ (фонетски лик указује на позајмљивање) односио само на кајкавско наречје. Почетком XIX в. „српски“ се односио на штокавске дијалекте, а не „хрватски“ (Нејлор 1996: 200). Ни сред. тога столећа хрватско се име није односило на штокавски, него се оно почело ширити на њега тек од 1843, са забраном „илирског“ имена (Кордић 2018: 272, 275). „Хрватско“ је име столећима имало другачије значење од данашњег, од XVII до сред. XIX в. ограничено на кајкавски; пре тога кајкавски се звао „словенским“ и „словинским“ (Кордић 2018: 267 , 271-272). За све то време хрватског имена за језик није било ни у Босни ни у Славонији, док се најраније, привремено у XVI в., јавило у Далмацији (Кордић 2018: 272-273), само за чакавски.

${ }^{19}$ Одабрани, еластичнији приступ омогућује да се бележи постојање различитих језичких система на истом подручју. Да смо узели пресек језичке ситуације у појединим сремским селима у XIX в., нпр., имали бисмо арбанаско-српски билингвизам. Различити језички системи у овом
} 
пању Хрвата у књижевнојезичку заједницу са Србима, почели су се гласније јављати дисонантни тонови у погледу етничког одређења овог језика. Томе је највећу тежину давао став В. Јагића, првог слависте тога времена, који је у више наврата доводио у сумњу, чак и не располажући доказима, „узрочну везу" између чакавског и штокавског с хрватским, односно српским именом (Јагић 1891: 390). Најснажнији је Јагићев утицај на јужнословенске прилике у време док је стајао на челу Бечке катедре за славистику (1886-1908), када је учествовао и у раду горњег дома скупштине Хабзбуршке монархије (свакако од његова повезивања са Штросмајером, до 1918). У приступној академској беседи Љ. Стојановић се уз уважавање осврнуо на Јагићево пристрасно виђење историје (1896: 26-29). До данас је остао задатак да се истражи и представи историјски континуитет српскога језика на читаву његову простору, без обзира на промене у прошлости.

У вези са српско-хрватским етничким разграничењем треба истаћи једну константу која се одржала од средине X в. до данас, а можда и из дубље старине: Константин VII Порфирогенит, наиме, прецизно одређује границу између српских и хрватских земаља на Цетини. С тиме у вези, неће бити случајност што држава Стефана Немање и његових потомака у своме највећем распону сеже управо до Омиша на Цетини, надомак Сплита (в. ИА 1999: $40,42) .{ }^{20}$ Иако су миграције драстично промениле распоред штокавских и чакавских говора, на Цетини је остала прастара копнена граница (уп. Ивић П. 2001: 36; Ивић П. 1994: 85; Лисац 2003: 15-16; Лисац 2009: 15-16; Пецо 1987: 37).

Због културне, књижевне и језичке, историјске и географске важности Дубровника, од XIX в. у хрватској науци се доказује да је древни говор овога града чакавски. У том смислу и Јагић је проблематизовао генезу меснога говора, полазећи чак од недоказане тврдње да је више пута поменуто хрватско име за словенски говор у овоме граду. На то питање са становишта дијалектологије, историје језика и изворне грађе М. Решетар је ставио тачку (2016: 0109). Пружени су докази из градског архива да се језик у принципу називао „српским” и „словинским”, у последњој фази још и „илирским” у XV-XVIII в. (М. Решетар, П. Колендић, М. Динић, Б. Недељковић, П. Ивић и др.). Изразом lingua seruiana најчешће се именовао језик текстова које су Дубровчани писали једни другима (Ивић П. 1991/II: 220; уп. Кордић 2018: 273). У званичним дубровачким документима на латинском Sclavonia је Србија, Sclavus - Србин; стога је и cancellarius sclav(ic)us - днғкь срьпскн (подробније Динић 2003: 163).

случају картографски се представљају шрафирањем или раздвајењем нивоа (на једној мапи би се приказао континуум српскога језика, на другој арбанаског). Исти случај имамо и данас у источној Србији: билингвални Власи који говоре српски и влашки, али то не смета постојању двојног идентитета и томе да се читав тај простор, између осталог, обухвати и српским језиком. Уосталом, многи су језички преци данашњих Срба имали у прошлости такву врсту идентитета.

${ }^{20}$ Српско етничко име помиње се на Цетини у локалним документима и доста касно, 1436 : и

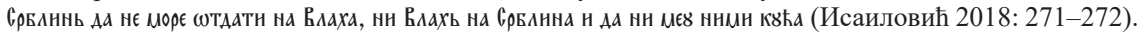


De mandato degli Signori officiali sopra la pramatica si grida, et proclama infrascritto tenore in lingua seruiana per maggior intelligenza di ogni uno alla loggia del Commune... 1638 (Ивић П. 1991/II: 208).

Од приближно 430 средњовековних докумената из Босне писаних на народном језику, од језика̂ једино се помиње српски, и то у пет исправа, док се српско име јавља око две стотине пута (Исаиловић 2018: 261-262, 273-275). Најпознатији су помени Срба у исправама бана Матеја Нинослава у којима се решава надлежност за спорове између „Срба” и „Влаха”, тј. житеља Босне и Дубровника (уп. Решетар 1891: 388). Са ширењем Босне на суседне, несрпске крајеве, уводи се државнополитичко одређење којим се обухватају сви, етнички хетерогени житељи ове државе из каснијег времена (уместо Србин - Бошњанин; уп. Исаиловић 2018: 265). Српски језик у овим документима односи се и на ијекавски и на икавски изговор - чак почетком XV в. у четири својеручно писана документа Прибислав Похвалић наводи да их је „Писао српски” (Решетар 1891: 288). За простор данашње Црне Горе није било посебних истраживања која би пратила српско име у историји јер се његово присуство подразумевало, али потврда је довољно. Овде прилажемо изводе из по једнога документа бана Матеја Нинослава и Прибислава Похвалића, а затим заглавље документа издатог кефалији Ђурђа Црнојевића о Ђурђеву убаштињењу на посед у Будви, преведен с италијанског на српски.

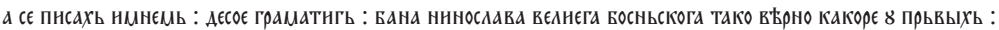



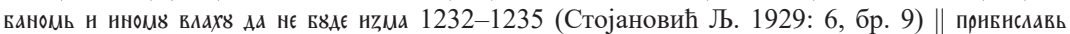

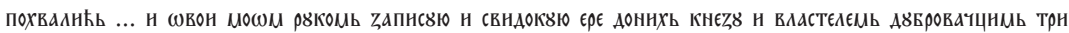

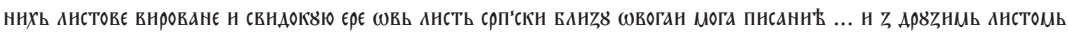


єМацьь за Арнєво прєпнсань нъ Аатннске срьБски 1493 (Томић 1909: 17).

Ширење српске државе јужно и југоисточно на рачун Византије и Бугарске и њено довољно дуго присуство на томе простору узроковало је померање српскога становништва, па тиме, можда и у ширем кругу, српских језичких црта, нарочито од краја XIII в. Тада у језички савез улазе представници српских и источнојужнословенских говора, који никада није прекинут. Поред добро познатог померања српске државе до простора данашње Грчке, преко читаве Македоније, југозападни простор данашње Бугарске ушао је у Милутиново краљевство (1282-1321) пре истека XIII в., а трајно је одбрањен као српска земља у Бици код Велбужда 1330 (в. мапе у ИА 1999: 42, 45-46, 48).

За Славонију из дубље прошлости није могуће ништа одређеније утврдити, јер је она рано укључена у мађарску државу, без неговања писмености на домаћем језику. Потребно је узети у обзир географске и историјске чиниоце и сагледати место славонских говора из перспективе лингвистичког центра и периферије. Под краљевином Славонијом у оквиру Угарске подразумевао се простор са средиштем у Загребу, а садашња Славонија, источније, о којој и ми говоримо, спадала је у угарске земље у ужем смислу речи (в. карту, нпр. за ХІІІ в., Фонт 2020: 319). Словенски назив ове области био је „Словиње”, односно „Словиња”, „Словинска земља”; назив „Славонија” 
прихваћен је из латинског језика (Динић 2003: 164). Етнолингвистички гледано, цео овај простор разбија се на два дела - кајкавски и штокавски, с оштријом првобитном границом него што је она између чакавског и штокавског (Ивић П. 1991/II: 188). То не треба мешати с данашњим стањем према којем су се на физичкој међи угнездили превасходно источнохерцеговачки говори. У историографији је показано да је главна српска земља из времена родовског друштвеног уређења формирана на линији спајања с овом облашћу: од ушћа Врбаса у Саву низводно десном обалом Саве, до ушћа Саве у Дунав (Живковић 2001: 13-17). Стога, говорна скупина с оцртаног простора представља лингвистичку периферију штокавског центра смештеног на тлу данашње Босне и Херцеговине, што је велики део Порфирогенитове „Крштене Србије”. С обзиром на трагове даљег континуитета у централној Словачкој с прелазним карактеристикама целог географског сектора, Славонија је транзитни простор који спаја Доњу Панонију са српским областима (у међувремену је тај контакт пресахнуо, уп. Ивић П. 1991/I: 196), у којем је могло бити предштокавских говора, са сложеним језичким развојем узрокованим реверзибилним усељавањем из Босне, и пре коначних померања с југа. Уосталом, није баш да нема помена да су славонски католици говорили или писали на српском језику. Познат је пример Сатира Матије Антуна Рељковића (уп. Кордић 2018: 273), али обично је да се језик ових штокаваца звао „славонским”, врло дуго с јасном разликом у односу на кајкавски, „хорватски” (в. Кордић 2018: 271-273; уп. нап. 39).

O Slavoncse tise verlo varash | Kö̈godmi tako odgovarash | Vashi Stari iesu knygu znali | Serbski shtili , a Serbski pisali. Al vi Sada nikako nechete Сатир илити дивји човик 1762.

Шта је главни критеријум у утврђивању присуства српскога језика? Српски фонолошки систем, ослоњен на српску артикулациону базу (о структурно-дијахронијском приступу у проучавању фонолошког система, у којем је већа важност генезе система од његова инвентара, в. Ивић П. 1991/I: 202). Овај систем у целом свом трајању у науци је добро познат (за системски преглед знатног броја говора в. ФО 1981), али веза између унутрашње и спољне историје српскога језика није у целости осветљена и прегледно приказана. Применом фонолошког критеријума лако можемо утврдити постојање и распростирање унутрашњим развојем изграђеног фонолошког система на јасно омеђеном простору до 1991/1992. године, који се на спољном плану очитује још као тип у односу на остале системе; потом системе који се наслањају на њега или зависе од њега; системе настале укрштањем овога с неким другим системом.

До сада није испуњен важан задатак српске, сада већ историјске дијалектологије - да картографски прикаже географско простирање српскога језика под његовим правим именом и његове релевантне контакте на терену. Кренимо с југа: говори српскога језика су сви говори призренско-тимочке зоне на северу Вардарске Македоније, на западу Бугарске, сви штокавски говори на тлу Србије, Црне Горе, Босне и Херцеговине, Хрватске и у околним државама, а то значи буњевачки у Бачкој, шумадијско-војвођански без остатка у Срему, сви говори у Рашкој, оба дијалекатска типа у Црној Гори и 
Приморју, дубровачки говор, источнобосански и западнохерцеговачки у Босни и Херцеговини, говори православних и унијата у Хрватској до Жумберка и у Словенији до Беле Крајине; исељенички говори, расути готово у свим правцима; дакле, без изузетка сви штокавски (уп. Вук 1849).

Показано је да чакавски нема властите индивидуалности (Ивић П. 1991/ III: 34-36). Тешко је говорити о чакавском наречју као о заокруженом дијалекатском блоку - то су чакавски говори, као део спољног прстена српскога језика на северозападном сектору (о периферијском статусу у односу на штокавски в. Ивић П. 1991/III: 36-37), обухваћени заједничким изоглосама у првом периоду (Ивић П. 1991/II: 185-187). Рани губитак хрватске државности (1102) који пада у период када су се свуда у словенском свету конституисали посебни језици, не дајући хрватској средини довољно времена за унутрашњу стабилизацију, удружен с потоњим неповољним историјским приликама, праћеним масовним досељавањем штокаваца, померених пред Турцима (XV в.), довео је до тога да чакавски говори остану ,замрзнути” у времену и без нарочитог унутрашњег везива које би их системом држало на окупу. Тако су чакавски говори претрајали до нашег доба као скрајнути и међусобно више-мање разбијени говори у дугом приобално-острвском ланцу. Слично, хрватско етничко име се рано изгубило на овом простору, да би тек у XIX в. доживело религијско-идентитетску обнову. Као што пољски језик има своје спољне дијалекте, кашупски и словињски, или као што словеначки има кајкавски, тако би се и у односу на српски језик могао одредити статус чакавскога, као генетски повезане скупине говора заосталих из раније прошлости по ободима прогресивнијег српскога језика (уп. Савић 2020: 345-346). Само у овакву контексту појам штокавског наречја би задржао вредност; у супротном, он би у србистици био излишан (Савић 2020: 343-344; уп. Ивић 2009: 5).

На источном и јужном терену српски је остварио контакте и значајно је утицао на развој месних говора; повратно је и сам претрпео утицај. Овде се, са становишта дијахроније, јавља проблем имена „македонског” народног језика, неодрживог за период ранији од 1944. године, без обзира на назив стандардног језика, јер нема таква имена у словенској језичкој прошлости, али - има „словенскога”. Друге природе је проблем с именом „бугарског” језика, јер столећима по досељењу Бугари нису сасвим асимиловали Словене, те није изгубљена свест о њиховој разлици (у том смислу, „старобугарски” језик је један из групе туркијских језика, не и „старословенски”). У раном периоду јесте постојао бугарски државно-политички идентитет који је био раширен на великом простору (у њега су, на широј линији, повремено улазили и Срби). Најбоље је, стога, говорити о источнојужнословенским говорима са српским елементима, у зависности од правца кретања и густине изоглоса, мешовитог карактера, али и о источнојужнословенским говорима под српским утицајем. Први случај је најзаступљенији у Вардарској Македонији; други у Бугарској и Грчкој. У Вардарској Македонији у обзир треба узети, пре свега, распрострањеност западнојужнословенских (српских) црта; ${ }^{21}$

\footnotetext{
${ }^{21}$ О њихову расипању на терену, идући ка југу, в. Ивић П. 1991/I: 96, Ивић П. 1991/I: 184186. Начелно о историјској динамици и врсти промена в. Конески 1966: 10.
} 
у Бугарској, пак, тзв. јатову границу. Уколико фонологија не би била једини критеријум, као мешовити говори могли би се приказати и они из призренско-тимочкога блока, али у том случају дијалекатски миље у који би се они уклапали, чинили би инословенски говори - сви који скупа творе језички савез. - Дакле, лингвистичка географија треба да прикаже и ово језичко преклапање на југу и истоку, као исход директних импулса који су долазили у историји из српскога језика, али и лингвистичку зависност чакавских говора од штокавског језичког система.

Приликом представљања степена сродства међу јужнословенским говорима и језицима ваља установити јасну појмовну структуру с утврђеном хијерархијом и не стављати термин језик где му није место. У случају српскога језика својеврсна је меронимија: надређен је појам језика (холоним), а подређени су му географски, национално, конфесионално или политички схваћени говори (мероними); сви су они део органске целине (однос целина-делови). ${ }^{22}$



Лингвистички узев, на средњејужнословенском говорном подручју један је народни језик. Као што се ниједан други језик у Европи не зове измишљеним или двојним именом (у суштини у оба случаја се ради о конвенционалним називима), „штокавски” (некада „илирски”) или „српскохрватски” („српски или хрватски” и сл.), може се искључиво звати својим природним именом, старијим, прецизнијим и историјски раширенијим од других „српским” (за границе штокавског наречја на терену в. Ивић П. 2001: 35-37; Ивић П. 1994: 85-88; Пецо 1987: 35-37).

\footnotetext{
${ }^{22} \mathrm{O}$ односу између српскога језика и његових варијаната у стандарднојезичкој равни в. Ковачевић/Шћепановић 2011: 49-58, уз чињеницу да је језичко јединство, оличено у неутралном, српском, задржано, при чему је очигледно да је српски исто што и некадашњи, привремени „српскохрватски” (уп. Ковачевић/Шћепановић 2011: 34-35). Не подлеже сумњи да је лингвистички то и даље један језик (Бугарски 2010: 33). У тој светлости српски језик је у социолингвистици „хипероним и кохипоним терминима хрватски, бошњачки/босански и црногорски језик.” Следствено, „као хипероним он једини има статус лингвистичког језика, док су сви остали само политички језици (језици само по имену), док су лингвистички искључиво варијанте српскога језика" (Исто: 57; уп. 34-35, 72-74, 151-152). Ово би се могло прихватити за период након растакања заједничког стандардног језика - ако се узајамна повезаност варијаната политички негира, али док је варијантност била мање изражена и практично сведена на источну и западну варијанту с јасном географском дистрибуцијом у оквирима једнога језика, без сумње се радило о меронимији, као у случају природног, народног језика. - Другачије стоје ствари са српским народним језиком, тамо где се он употребљава данас код других народа, његово име не може бити кохипоним. Српски језик на органском плану, осим ако се не узима у обзир скуп више језичких система (јужнословенских и др.), стоји на врху пирамидално повезане језичке скупине, с различито хијерархизованим степенима сродства, у самој бази оствареној као јасно дефинисан део говорнога континуума, упркос већим или мањим поремећајима на терену, изазваним померањима становништва.
} 


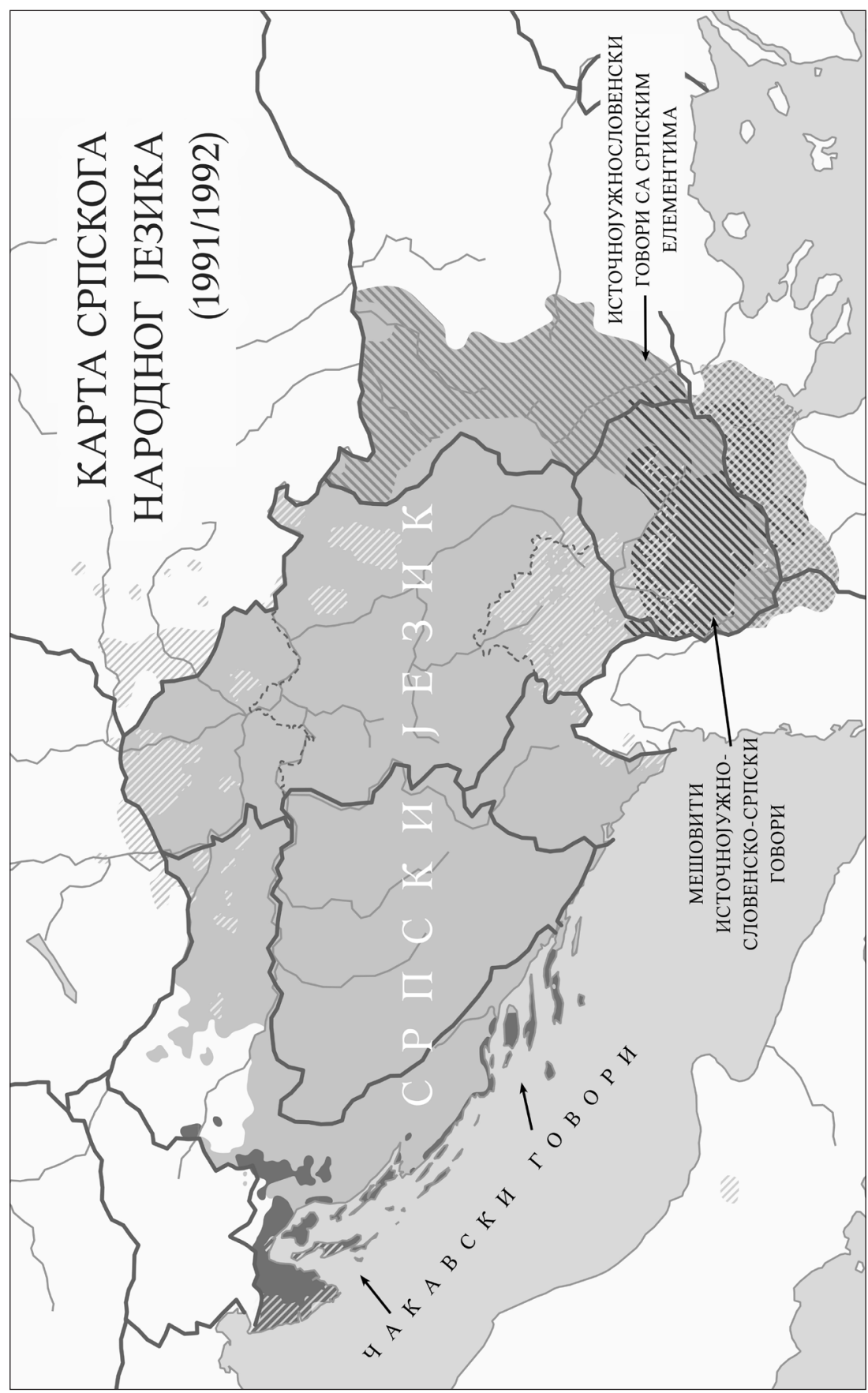


Без обзира на ужи план или поље истраживања србистика мора имати за предмет српски језик као целину, било да се ради о српским говорима или о онима који то нису, „стриктно поштујући при том чињеницу да они нису српски у националном смислу" (Ивић 2009: 9). Дакле, наша је дужност да помиримо лингвистику и социолингвистику, али не на штету чињеница и језичке историје. ${ }^{23}$

\section{ИЗВОРИ И ЛИТЕРАТУРА}

Брозовић 1970: D. Brozović, Standardni jezik, Zagreb.

Бугарски 2001: R. Bugarski, Sociolingvisitičke teme, Beograd.

Бугарски 2010: R. Bugarski, Jezik i identitet, Beograd.

Вук 1849: Вук Караџић, Срби сви и свуда, Ковчежић за историју, језик и обичаје Срба сва три закона, Беч, 1-27.

Динић 2003: М. Динић, Из српске историје средњега века, Београд.

EJ 1955: Arbanasko-južnoslavenski odnosi, Enciklopedija Jugoslavije, 1, Zagreb, 166-167 (H. Barić).

Живковић 2001: Т. Живковић, О северним границама Србије у раном средњем веку, 3бМСИ 63-64, 7-17.

ИА 1999: М. Благојевић (гл. ред.), Историјски атлас, Београд.

Ивић А. 1922: А. Ивић, О српском и хрватском имену, Београд.

Ивић М. 1996: M. Ivić, Pravci u lingvistici, Beograd.

Ивић П. 1991/I-III: П. Ивић, Изабрани огледи, I-III, Ниш.

Ивић П. 1994: П. Ивић, Српскохрватски дијалекти, юихова структура и развој, I, Сремски Карловци - Нови Сад.

Ивић П. 2001: П. Ивић, Дијалектологија српскохрватског језика, Сремски Карловци - Нови Сад.

Ивић 2009: П. Ивић, Српски дијалекти и ґихова класификација, Сремски Карловци - Нови Сад.

Ивић П. 2018: П. Ивић, Дијалекти. Расправе, студије, чланции, 2, Сремски Карловци - Нови Сад.

Исаиловић 2018: Н. Исаиловић, Помени српског имена у средњовековним босанским исправама, Српско средњовековно писано насљеђе и историја средњовјековне Босне и Хума, Бања Лука - Источно Сарајево, 261-282.

Јагић 1864: V. Jagić, Iz prošlosti Hrvatskoga jezika, Književnik I, 332-358, 447-485.

\footnotetext{
${ }^{23}$ Наравно, не треба очекивати да ће инострана славистика која се држи својих традиција и практичних, избалансираних ставова, мењати однос према сада раширеном појмовно-терминолошком апарату. Оно што је за нас, из историјских разлога српски, за њих ће бити „српско(-) хрватски“, с могућношћу постојања и знатно неадекватнијих форми (попут „ВСМS“; уп. Кордић 2018: 130-132). У српској традицији, која се наслања на народну историју, коришћено је једноделно име; у хрватској филолошкој традицији од друге половине XIX в. шири се дводелно име (Кордић 2018: 127-128), па је, посебно када се има у виду историја усвајања овог имена, то уступак хрватској култури.
} 
Јагић 1891: V. Jagić, Einige Bedenken, aus Anlass der vorhergehenden Abhandlung Dr. Rešetar's, $A S P h$ XIII.

Јачов 1986: М. Јачов, Списи Конгрегащије за пропаганду вере у Риму о Србима (1622-1644), I, Београд.

Ковачевић/Шћепановић 2011: М. Ковачевић, М. Шћепановић, Српски језик у вртлогу политике, Никшић.

Колендић 1964: П. Колендић, Из старога Дубровника, Београд.

Конески 1966: Б. Конески, Историја македонског језика, Београд, [Скопље].

Кордић 2018: S. Kordić, Jezik i nacionalizam, Zagreb.

Лисац 2003: J. Lisac, Hrvatska dijalektologija, 1, Zagreb.

Лисац 2009: J. Lisac, Hrvatska dijalektologija, 2, Zagreb.

Миклошич 1858: Fr. Miklosich, Monumenta Serbica, spectantia historiam Serbiae Bosnae Ragusii, Viennae.

Нејлор 1996: К. Е. Nejlor, Sociolingvistički problemi među Južnim Slovenima, Beograd.

Пецо 1989: А. Peco, Pregled srpskohrvatskih dijalekata, Beograd.

Пипер 1988: П. Пипер, Непознате свеске универзитетских предавања Ватрослава Јагића, 3бМСC 35, 75-82.

Радовановић 2003: M. Radovanović, Sociolingvistika, Sremski Karlovci - Novi Sad.

Решетар 1891: M. Rešetar, Die čakavština und deren einstige und jetzige Grenzen, ASPh XIII, 93-109, 161-199, 361-388.

Решетар 1938: М. Решетар, Увод. Српски молитвеник од г. 1512, Два дубровачка језична споменика из XVI вијека, Београд, XI-LX.

Решетар 2016: Решетарова приступна беседа у Српској краљевској академији, СМ 2016, 03-0113.

Савић 2020: В. Савић, Српско културно наслеђе, његова угроженост и могућа решења, оком једнога филолога, Српски културни простор: устројство, проблеми, вредности, 1, Нови Сад, 333-350.

СМ 2016: Српски молитвеник. Споменица Милану Решетару (1512-19422012), Београд.

Стевановић 1975: М. Стевановић, Савремени српскохрватски језик, I, Београд.

Стојановић J. 2011: Ј. Стојановић, Путевима српског језика и ћирилице, Никшић.

Стојановић Љ. 1896: Приступна академска беседа Љуб. Стојановића, Глас CKA LII, 1-29.

Стојановић Љ. 1929: Љ. Стојановић, Старе српске повеље и писма, 1, Београд - Ср. Карловци.

Томић 1909: J. Н. Томић, Прилози за историју Црнојевића и Црне Горе (1489-1536 год.), Споменик CКА XLVII, 1-48.

ФO 1981: P. Ivić (gl. red.), Fonološki opisi srpskohrvatskih/hrvatskosrpskih, slovenačkih i makedonskih govora obuhvaćenih opšteslovenskim lingvističkim atlasom, Sarajevo.

Фонт 2020: M. Font. Rostislav, dominus de Macho, Стефан Првовенчани и његово доба, Београд, 309-326. 


\section{Viktor Savić}

\section{SERBIAN SPEECHES AND/OR THE SPEECHES OF THE SERBIAN LANGUAGE}

\section{Summary}

This study focuses on the analysis of the South Slavic language landscape in diachronic and diatopic frameworks, in the centre of which stand the field distribution and the linguistic autonomy of the Serbian language, i.e. of the Serbian language system. The problem is basically manifested at two levels: logical and geographical. The preconditions for dealing with this problem are met: a rich historical fact-based database and extensive and diverse dialectological research. It is established that the reduction of the "Serbian language" as an [abstract] entity to "Serbian speeches" is a pseudo-scientific construct, and the place of "other speeches" in a unified language system is examined. The goal is to determine and map the true scope of the Serbian language and its intrinsic determination against the neighbouring Slavic language systems, regardless of the political and national borders established in recent historical and political events. It is concluded that in the field, "Serbian speeches" and "the speeches of the Serbian language" constitute the Serbian language system, or the "Serbian language", by unambiguous genetic connections, through hierarchical forms of kinship.

Key words: Serbian language, Serbian speeches, speeches of the Serbian language, language history, dialectology, linguistic geography. 